Információközvetítés és közösségépítés - multifunkciós könyvtári hálózatok.

Szerk. Kiszl Péter, Németh Katalin. Budapest, ELTE BTK

Könyvtár- és Információtudományi Intézet. 2020. 287-294.

\title{
OLDÁS ÉS KÖTÉS A VIRTUÁLIS KÖZÖSSÉGÉPÍTÉSBEN KÖNYVTÁRI TUDÁSKÖZVETÍTÉS A KÖZÖSSÉGI MÉDIÁBAN
}

\author{
FODOR JÁnOS
}

\section{TARTALMI ÖSSZEFOGLALÓ}

A 2000-es évek közepén a publikálást és tájékozódást forradalmasító Web új funkcióval bővült: a nyilvános interakció lehetőségével. A könyvtártudomány számára a tájékozódási közegek, mérhető aktivitások, visszajelzések rendszerei megteremtették az olvasókkal évszázadok alatt kialakult, hagyományos interakció virtuális duplikálásának esélyét, igényét. A közösségi hálózatok kialakulásának pillanatában reálisnak tünt, hogy élő közösséget alkossanak olvasók gyüjtemények, tudástárak körül. A 2010-es évekre vált nyilvánvalóvá, hogy a gyüjteményi jelenlét saját homogén közeget képezni gyenge, a közösségi média hírfolyamaiban csak elkeveredve kaphat figyelmet. A 2020-as évek jól felfogott célja így az, hogy e keverékből lehetőség szerint oldat váljon. A közösségi médiát átjáró, érdeklődést megkötő, tudásközvetítő hatás a könyvtár jövőképének egyik megoldása. Megteremtése szakmai kötelességünk.

Az ezredfordulóra szoktunk hozzá a weboldalak, honlapok globális rendszeréhez, a virtuális nyilvánosság írást, olvasást átformáló létezéséhez, de a World Wide Web az új évezred első évtizedében máris radikálisan átalakult, s a technológiai fejlődés messze túllépett a bárki által elkészíthető HTML oldalak funkcionalitásán. A statikus weboldalak böngészhető világhálózata fokozatosan kibővült a nyilvános interakció lehetőségével, ahogy adatbázis alapú, mindinkább uniformizálódó tartalomkezelő rendszerek foglalták el a webcímeken elérhető webhelyeket. Az adatbázis alapú tartalomszolgáltatás egyúttal az összeköttetés lehetőségét is biztosította az offline, vagy belső hálózatokba zárt intézményi adatbázisokkal. A könyvtárak, gyüjtemények, archívumok így valós esélyt kaptak arra, hogy egyenrangú, sőt, felhalmozott tudáskincsük révén helyzeti előnnyel induló versenytársai lehessenek a weben megjelenő új, natív szolgáltatásoknak, közösségi oldalaknak vagy felhasználói együttműködésből létrejött tudástáraknak. A könyvtártudomány számára a digitális tájékozódási közegek, a mérhető aktivitások, a felhasználói visszajelzések algoritmizálhatóan mérhető rendszerei megteremtették az olvasókkal évszázadok alatt kialakult interperszonális, hagyományos interakció virtuális duplikálásának esélyét, igényét. 
FODOR JÁNOS

Ahogy a kibertér, a virtuális, párhuzamos virtuális valóság kialakulásában is fordulópontnak tűnt az új évezred első évtizedének dereka, a közösségi hálózatok kialakulásának pillanatában az is reálisnak tűnt, hogy hálózati közegben élő közösséget alkossanak az olvasók gyüjtemények, tudástárak körül. A Könyvtár 2.0 (Library 2.0) mozgalom ${ }^{1}$ ennek az optimista, technológia által továbblépő könyvtárképnek a lenyomataként ma már nosztalgikus érzéseket kelt akkor is, ha az akkor új lehetőségek - azonnali kapcsolattartás a weben, közösségi címkézés, adatbázisok arathatósága, mash-up szolgáltatások kiszolgálása, könyvtári jelenlét blogbejegyzésekben és közösségi médiában - mindennapjaink részévé váltak.

A 2010-es évekre nyilvánvalóvá vált, hogy a gyüjteményi jelenlét saját, homogén célközeget képezni erőtlen, a webes felhasználói aktivitásokat kisajátító közösségi média hírfolyamaiban csak elkeveredve kaphat esetleges figyelmet. A 2020-as évek jól felfogott célja így az, hogy e keverékből lehetőség szerint oldat váljon. A közösségi médiát átjáró, érdeklődést megkötő, tudásközvetítő hatás a könyvtár jövőképének egyik megoldása.

Megteremtésére törekedni szakmai kötelességünk, bár a siker korántsem borítékolható.

\section{A kivilágítatlan iparváros}

Vélhetően viszonylag kevesen ismerték, s gyászolták Magyarországon John Perry Barlow-t, az Electronic Frontier Foundation alapítóját. Hazai nekrológírója megkésett figyelemfelhívásként így foglalta össze az elhunyt netteoretikus eszmei örökségének sorsát: „bár a múlt század kilencvenes éveinek végén, sőt még a mostani elején is úgy tűnt egy ideig, hogy a cyberspace-ben összegyülő, anonim fórumokban (kiberközösségekben!) világmegváltó terveket forraló, a hekkeretikát a zászlójukra tüző, az MIT és a Caltech emlőin nevelkedő, a Wiredet Bibliaként tisztelő, a Szilícium-völgyet Mekkájuknak tekintő zokniszandálos kiberforradalmárok sikerrel vehetik fel a küzdelmet a gyülöletes, örökölt elittel, a buta bankárokkal, a pökhendi politikusokkal és a hatalomvágyó hadvezérekkel, akik ellen Barlow meghirdette a forradalmat, mostanra teljesen nyilvánvaló, hogy ez a forradalom elbukott." ${ }^{2}$ Az Internet korai, lelkes teoretikusai lassan feledésbe merülnek, de Barlow-nál maradandóbban ismertebbé vált Ted Nelson és Tim-Berners Lee, a dokumentumkezelés globális, digitális rendszerét megálmodó hipertext-úttörő, illetve az azt gyakorlatban megvalósító, méltán lovaggá ütött matematikus neve. Az ő gondolataik, törekvéseik nyomán létrejött világháló azonban csodálatba keveredő csalódások lépcsőzetes sorozatát hozta, $s$ megálmodója, ${ }^{3}$ innovátora figyelmeztetéseire ${ }^{4}$ ügyet se vetve, önjáró, piaci törvényszerüségek igájába beálló, megállíthatatlan rendszerként és infrastruktúraként terebélyesedett el mindennapjainkon. A bárki számára hozzáférhető, szabadon használható és konvencióktól, kánonoktól szabad identitást kínáló világhálóból mára valami egészen más lett, ${ }^{5}$ a milliók által használt szolgáltatá- 
sok napjaink nyomasztó monopóliumai, amelyek befolyása életünkre nagyobb, mint bármilyen korábbi cégé a világtörténelem során.

E virtuális valóság hétköznapivá válása annyira szokatlan és gyorsan kialakult helyzet, hogy nehezen hasonlítható bármilyen, az emberiség történetében korábban megélt szituációhoz, állapothoz. A tenyér-képernyőkbe horgadó arcok sora a közlekedési eszközökön, a tudás és hitelesség minden szintjének megkérdőjelezése, az áltudományos, vagy kifejezetten káros elképzelések megállíthatatlan terjedése sötét, disztópiába illő világot idéz. S talán nem is baj, ha biztató jelek, oázisként megtapasztalható rétegigények helyett olykor józanul, e hétköznapi, aggasztó élményeinket extrapoláljuk: munka előtt, után (és közben), magunkra fordítható pillanatainkért jól érzékelhető verseny zajlik, szemlélődés helyett kitölti figyelmünket a virtuális valóság. Telefonon játszunk, véget nem érő, képközpontú posztsorokat görgetünk, gyors üzeneteinket ezen közben váltjuk, legföbb kompetenciánk a multitask lett. Az összefüggő szabadidő és a munkaidő között akkora a kontraszt, hogy radikálisan kiszakadva, az élményeket túladagolva igyekszünk előbbit megélni, eltölteni.

Mintha egy sötét, közösségi terektől, intézményektől mentes, végletekig optimalizált iparvárosban töltenénk hétköznapjainkat, amelyből úgy kell elrugaszkodni, elutazni a jó levegőért, fényért. Elmélyült tájékozódáshoz, olvasáshoz se fény, se idő: a hírek politikáról, kultúráról, életmódról félreértelmezhetőek, torzultak, mint a sötétben fülbe súgott pletykák a futószalag mellett, munka közben. Lídszöveg, sőt clickbait-címsor rövidségben, véleménybuborékokba szerkesztődve terjednek a külvilágról töredékes képet eszkábáló tudósítások, s váltják ki kurta, sommás reakcióinkat: többre nincs időnk. A szóbeliség illékonysága, bizonytalansága hosszú távon is kísért, a „digital dark age” korszakává6 válhat jelenünk: sem írásbeli, sem képi hagyatékok nem maradnak utánunk a padláson utódainknak, mert mindenünket (kommunikációt, naptárat, írásokat, képeket, kapcsolatainkat) cégekre, jelszóval levédett, bármikor megszűnhető és megszüntethető adatbázisokra bíztuk. A könyvtárba járásnak, mint minden más utánajárásnak, ügyintézésnek az applikációk, adatbázisok használata feleltethető meg. Erény, már-már extra-kompetencia, ha valaki képes a közösségi média és játékok falain kívül is boldogulni, „, hagyományos” weboldalakat böngészni, saját rétegérdeklődésén túllépni. Ügyességnek számít, ha időveszteség nélkül, két üzenetváltás között intézkedik, ha mobileszközről, az utcáról meg tudja venni vonatjegyét, leadja adóbevallását, vagy rákeres egy könyvtári adatbázisban egy kérdéses névre, eseményre.

Az okostelefonok testre szabása, telepített alkalmazásokkal továbbokosítása, az okos háztartások beállítása jövőbe rohanó korunkban a sokoldalúság olyan fokmérője, mint korábban az ezermesterség volt. A hatékonyság ilyetén növelésével látszólag időt takarítunk meg, azonban a valóságban inkább piacot, teret nyitunk az időnkért versengő szolgáltatásoknak és - ahogy az állandó elérhetőségünkkel - a munkáltatók által ránk mérhető újabb feladatoknak. 
FODOR JÁNOS

\section{Több lábon sem biztosan}

A közösségi és kulturálódási terek iránti vágy, kihasználásuk hatékonyságának növelése, a technológiai naprakészség igénye és a tájékozódási kompetenciák elégtelensége szinte természetes módon, a technológiai változás mellékhatásaként jelölte ki a könyvtári funkciók bővítési lehetőségeit. Elvonatkoztatva a helyi adottságoktól, a könyvtárakra s általában a kulturális-tudományos intézményekre fordított fenntartói és kormányzati figyelem globális variációitól, a több lábon álló könyvtár a legoptimálisabb körülmények között sem biztos recept, bár kétségtelenül az egyetlen lehetséges fejlődési irány. A felhasználók idejéért, aktivitásáért folytatott versenyben a komplexitásra törekvés magában rejti a célorientált, egyszerübb szolgáltatásokkal folytatott - sok esetben nemes és inspiráló - versengés nehézségeit:

- Közösségi térként a könyvtárnak egyéb közösségi terekkel - kávézóktól klubokon keresztül közterekig, számos vonzó lehetőséggel - kell konkurálnia.

- A technikai ismeretterjesztés, a gyakorlati tanfolyamok, s a kevesek által megfizethető technológiák hozzáférhetőségének biztosítása jelentős beruházásokkal éppúgy része lehet a könyvtár portfóliójának, mint célorientált közösségi mühelyeknek, laboroknak.

- Bemutatók, estek, előadássorozatok megrendezésében hasonlóan erős hagyománya van közösségi házaknak, kulturális vagy müvelődési központoknak, ezek hiányában - részben - könyvesboltoknak, kluboknak, önszerveződő közösségi tereknek.

- A könyvtár helyet adhat kiállításoknak, tárlatoknak, roll-up installációknak, de a közmegegyezés inkább köti a vizuális információátadást a galériákhoz, vagy a napjainkban szintén megújuló, komplexitással kísérletező múzeumi terekhez.

- A könyvtár, mint önálló kutatást és közös munkát egyaránt támogató tanulási környezet az oktatást irányító iskola felszereltségének, kialakításának és struktúrájának függvénye. A könyvtár saját terével és szolgáltatásaival annak része, kiegészítője vagy hiányainak pótlója is lehet, de optimális esetben számos szolgáltatását egy jól felszerelt iskolai oktatási környezet is képes biztosítani.

- Tudományos kutatást támogató környezetként a könyvtár versenytársai kutatóhelyek, intézetek, levéltárak, archívumok maradnak a jövőben is, a hatékonyság jegyében terjedőben a kutatóhelyekre kihelyezett könyvtáros szerepköre $^{7}$ - s természetesen folyamatosan gyarapodnak, okosodnak a digitalizált tudás otthonról is, mobil eszközökről is elérhető adatbázisai.

- Klasszikus, legbiztosabb, más intézmény által soha el nem vitatott szerepkörként a könyvtár továbbra is azonosítható a gyüjtött, felhalmozott, rendszerezett könyvek táraként, s bármennyire félreérthető, muzeális árnyalatú ez a szerepkör ma, a digitális dokumentumtárak korában, a szerteágazó tevékenységek és szolgáltatások összetartó ereje, a kohézió nem lehet más, mint a fizikai 
jelenlét indokoltsága. Vagyis az, hogy az adott földrajzi helyen, tudományos szakterületi szerkezetben vagy intézményi struktúrában saját jogán is mással nem pótolható értéke van egy múlttal kapcsolatot teremtő, feltárt tudásgyűjteménynek és a ráépülő, abban szakértő könyvtári szolgáltatásnak.

Szakkönyvtárak esetén a szakirodalom-feltáró, kutatást-segítő műhelymunka, regionális könyvtárként a régió, település tudástáraként végzett feltáró és kreatív munka az az arculatot adó, alapvető funkció, amelyre lehetőség szerint épülhetnek további, komplex funkciók, szolgáltatások. Kutatásaink bizonyították ${ }^{8}$, hogy érdemes ezt az egyedi arculatot kidomborítani, plasztikussá tenni, megjeleníteni a weben a közösségi médiában, mert a gyűjtemény (az egyedi gyüjtőkör), a lokáció (specializáció) és a munkatársak szakemberként felértékelése, elötérbe helyezése biztosíthatja, őrizheti meg a könyvtárt önálló entitásként a XXI. században.

\section{Oldás és kötés}

Visszatérve a korábban felvázolt, sötét disztópiánkhoz, a technológiai változások mára nem csak a könyvtár hagyományos társadalmi szerepköreit helyezték új kontextusba, de a technológiai fejlődéstől hajtott, korszerü digitalizálási tevékenység megitélését is. A közösségi médiában megvalósuló tartalomfogyasztás és a horizontális média kialakulása a tudományos és kulturális kánonok felbomlásához, az információkat hitelesítő közmegegyezés és szakmai értékrend megkérdőjeleződéséhez vezettek.

Ha minden megnyilvánulás mögött manipulációt, torzítást, csoportérdeket sejtünk, s az információ formálásának összes szintjére - amatőr és profi aktusára - gyanú vetül, akkor szükségszerüen fölértékelődik a „nyers”, eredeti állapotában archivált információ. A publicisták, szerzők, szerkesztők által újraszerkesztett részigazságoktól szívesen fordulunk a teljes, hiteles dokumentumok tárai felé, ha azok fölkínálkoznak. Eszköztárunk részeivé tesszük őket, ha hasznosnak és jól kezelhetőnek bizonyulnak. A digitalizált tudástárak ritka, de sikeres közösségi média jelenléte bizonyítja, hogy megfelelő aktivitással hiányt pótló tényezővé válhatnának a digitális tartalomfogyasztásban. Ezt azonban régi beidegződések is gátolják.

A „hosszú távú megőrzés” vagy a „virtuális gyüjtemény” szókapcsolat máig mintha a kincskereső játékok hangulatát viselné: a digitális gyűjtemény önmagába zárt rendszerként vár felhasználójára, hogy odanavigáljon, eligazodjon benne, s az ott keresett, megtalált értéket saját felhasználásra kimenekítse. Hiába tudható, hogy jól digitalizált tudáselemekre egymással kombinálható lekérdezési rendszerek épülhetnek, - így biztosítva, hogy a jövő kutatási, publikálási és kommunikációs rendszerei a múlt megbízható tudástáraiból is táplálkozhassanak - ismereteink átkonvertálása a kultúra megújuló erőforrásává munkaigényes és - a számtalan forrás ismeretének függvényében - új egyenlötlenségeket szül. 
FODOR JÁNOS

Lehet bármilyen összetett és gazdag egy újonnan létrehozott digitális gyüjtemény, a köztudatban jó esetben csak nyitólapja marad meg, mint a hely, ahol „abban a témában a régi dolgok fönt vannak". Okolható ezért informatikushiány, a rövid távú gondolkodásban a pályázati finanszírozás, de sokszor a gyüjtemények kezelője is projekt-végcélként tekint a gondjaira bízott állományrészek digitalizálására, a jövőt az IT-szakemberekre és a könyvtártudomány későbbi fejlődésére, integráló törekvéseire hagyva. A létrehozás során közremüködő programozók igyekeznek egyszerüsíteni az adatszerkezeten, a közönség pedig egy újabb, megjegyzendő, megértendő passzív keresőfelületként fogadja el az eredményt.

A közreadott tudásra rálátó szakemberek - döntően - változatlan munkakörben, a digitalizálás alapjául szolgáló gyüjteményben dolgoznak tovább, s velük a lehetséges kapcsolatok, a bővítő, összefüggést teremtő asszociációk is elszakadnak a digitalizálva önálló életre kelt adatbázistól.

Ha nem alakul ki a digitális gyüjteményekre épülve egy új, markánsan elkülöníthető átmeneti szakma vagy szakterület, amelytől a majdani automatikus feltáróajánló algoritmusok kreativitást, mesterséget „tanulhatnak”, akkor gyüjteményeink szerepe a múlt tudásának passzív lerakataiként rögzülhet. A feldolgozó, rendszerező, ajánló és kutatást, tájékozódást segítő kompetenciák birtokában a könyvtáros szakemberek képesek e kihívásnak megfelelni, s valójában semmilyen más, létező szakma képviselői nem is helyettesíthetik őket ebben a tevékenységben. A feladat nem csak a digitalizált gyűjtemények továbbfejlesztése, annak instruálása, hanem a közvetlenül elérhetővé tett, online állomány bekötése is korunk tömegkommunikációs vérkeringésébe, megjelenítése ott, ahol az olvasók legtöbb idejüket eltöltik.

A közösségi média tartalom-folyamában a könyvtár megjelenhet ugyan rokonszenves közösségi helyként, optimális tanulási, kutatási környezetként és a technológiai ismeretterjesztés barátságos helyszíneként, de egyedi, eredeti tartalmat csakis gyűjteményére építve, munkatársai tájékoztató szakértelmével alkothat és publikálhat. A könyvtár egyedi arculatát, a szerteágazó funkciókat összefogó gyüjteménygondozó tevékenységet éppen azért kell megjeleníteni, beleoldani a közösségi média hírfolyamába, hogy a XXI. században is kívánatossá tegyük a könyvek tárával szimbolizált tudástárat közösségi térként, mühelyként, professzionális tájékoztató közegként.

A biztos, hiteles, átdolgozatlan információk értő, kreatív válogatásával, képek, dokumentumok, összefüggések kollázsaival ${ }^{9}$ érdeklődés kelthető és kötődés generálható, amely átível véleménybuborékokon, bizalmatlanságon, egymást keresztező értékrendeken és generációkon.

\section{A jelenböl buborék, a múltból közösség}

Sokan a Facebook hanyatlásának tünetét látják a felhasználók átlagéletkorának növekedésében, a személyes posztok visszaszorulásában és az emlékek, nosztalgikus visz- 
szatekintő bejegyzések sokasodásában. ${ }^{10} \mathrm{Az}$ új technológia használata, a naprakészség igénye és a vélemény-buborékoknak kitettség összefüggése az idősebb nemzedékek vonatkozásában eddig inkább a veszélyek révén került az érdeklődés középpontjába. ${ }^{11}$ Látnunk kell azonban azt is, hogy természetes kiegyenlítődésről is szó van, jól érzékelt igények is munkálnak e változás mögött. „Az elkövetkező évtizedekben három olyan problémával kell farkasszemet néznünk, amely egységes generációs identitás után kiált: a klímaváltozással, az egyre növekvő társadalmi és jövedelmi egyenlőtlenségekkel és a technológia térhódításával. E három jelenség fényében a generációk múltbéli jegyei teljességgel lényegtelenné válnak, és függetlenül attól, ki melyik nemzedékhez tartozik, mindenkinek választ kell adnia abban az élethelyzetben és azzal az eszköztárral, amely rendelkezésére áll." 12

A generációkutató megfigyelése több szempontból is tanulságos: a webtartalom jellemzője, hogy összemossa az idősíkokat, jóformán azonos eséllyel jelennek meg kereséseink nyomán friss és több éves, de népszerű publikációk. A hálózati kommunikációban sincs jelentős szerepe az időzónáknak, és - a tartalmak nagy olvasztótégelyeként - a közösségi média sem a publikálók életkora szerint rendezi az elénk kerülő bejegyzéseket. A különböző korosztályokat egyaránt érdeklő, véleménysemleges témák keveredésére, filter-buborékokon áthatoló terjedésére így több az esély, mint bármilyen korábbi kommunikációs csatornán. Ha feltételezzük, hogy a múltban felhalmozott tudás - érdekesen tálalva - ilyen témákat kínálhat, a könyvtárak, gyüjtemények szakmaisága által hitelesített információk létrehívhatnak érdeklődési közösségeket, közös kommentelésre, egyéni továbbosztásra késztethetnek egymástól minden tekintetben távol álló olvasókat, s felkelthetik figyelmüket a gyüjteményre.

Míg a jelen megítélése, a friss hírek értelmezése - úgy tűnik - elkerülhetetlenül elválaszt és határokat állít vélemények, világnézeti különbségek mentén, az idősebb nemzedék fogékonysága a közösen megélt múlt témáira, s a jelenhez magyarázatot, fogódzót, hiteles alapokat kereső fiatalabbak igényei olyan közös nevezőt képeznek, amelyre - az egységes generációs identitás megerösödését támogatva - reflektálnia kell a könyvtárnak.

\section{Irodalom és jegyzetek}

1. HOLMBERG, Kim [et al.]: What is Library 2.0? = Journal of Documentation, 65. vol. 4. no. 2009. 668-681. p. Forrás: https://doi.org/10.1108/00220410910970294 [2019. április 22.]

2. Anarki: John Perry Barlow meghalt, a kiberforradalom elbukott. = Qubit, 2018. február 8. Forrás: https://qubit.hu/2018/02/08/john-perry-barlow-meghalt-a-kiberforradalomelbukott [2019. május 20.]

3. NELSON, Ted: Where World Wide Web Went Wrong. = Xanadu.com. Forrás: http:// www.xanadu.com.au/xanadu/6w-paper.html [2019. május 7.] 


\section{FODOR JÁNOS}

4. BERNERS-LEE, Tim: 30 years on, what's next \#ForTheWeb? World Wide Web Foundation, 2019. március 12. Forrás: https://webfoundation.org/2019/03/web-birthday-30 [2019. május 30.]

5. STALTZ, André: The Web Began Dying in 2014, Here's How. = Staltz.com, 2017.október 30. Forrás: https://staltz.com/the-web-began-dying-in-2014-heres-how.html [2019. május 16.]

6. CERF, Vint: „Digital Vellum and Archives” = The Networking and Information Technology Research and Development (NITRD), 2016.08.12. Forrás: https://www.nitrd.gov/ nitrdgroups/index.php?title=DigitalVellumAndArchives [2019. május 12.]

7. KOLTAY Tibor - ŠPIRANEC, Sonja - Z. KARVALICS László: Research 2.0 and the future of information literacy. London, Chandos Publishing, 2015. Forrás: https://doi. org/10.1016/B978-0-08-100075-5.00003-1 [2019. július 1.]

8. FODOR János: Megosztás vagy szerkesztés? - A könyvtár változó szerepe a közösségi médiában. = Tudományos és Müszaki Tájékoztatás, 64. évf. 1. sz. 2017. 24-36. p.

9. KISZL Péter - FODOR János: The „Collage Effect”. Against filter bubbles. Interdisciplinary approaches to combating the pitfalls of information technology. = Journal of Academic Librarianship, 44. vol. 6. no. 2018. 753-761. p. Forrás: https://doi.org/10.1016/j. acalib.2018.09.020 [2019. május 27.]

10. WOOD, Molly: The Rise and Fall of Facebook's Memory Economy. $=$ Wired, 2019. április 26. Forrás: https://www.wired.com/story/rise-fall-facebooks-memory-economy [2019. május 28.]

11. HANULA Zsolt: Nem a gyerekeket kell félteni az internettől, hanem a nyugdíjasokat. = Index.hu, 2015. szeptember 10. Forrás: https://index.hu/tech/2015/09/10/nem_a_gyerekeket_kell_felteni_az_internettol_hanem_a_nyugdijasokat [2019. május 29.]

12. NEMES Orsolya: Generációs mítoszok: Hogyan készüljünk fel a jövő kihívásaira? Budapest, HVG Könyvek, 2019.

Fodor János az ELTE BTK Könyvtár- és Információtudományi Intézet egyetemi adjunktusa. Kutatási területei: digitalizálás, közösségi média, gyüjtemények webes megjelenítése, hálózati tájékoztatás kulturális területeken, kortörténet, helytörténet, kommunikáció- és információtörténet.

ORCID: 0000-0001-7749-7623 